\title{
Essential Oil Compositions and Antimicrobial Activity of Piper arborescens Roxb.
}

\author{
Wan Mohd Nuzul Hakimi Wan SALLEH, Farediah AHMAD, Heng Yen KHONG
}

\begin{abstract}
The essential oils obtained from the leaves and stems of Piper arborescens by hydrodistillation were analyzed by GC and GC-MS. Fifty components have been identified from the leaves and stems oils, comprise of thirty six (97.5\%) and forty six (90.5\%) components, respectively. The most abundant components in the leaves oil were $\beta$-phellandrene $(24.3 \%)$, sabinene (16.3\%), $\alpha$-pinene (10.4\%) and terpinen-4-ol (7.2\%), while $\beta$-phellandrene (20.4\%), methyl eugenol (11.0\%) and $\beta$-caryophyllene $(9.0 \%)$ were the main components in the
\end{abstract}

stems oil. The essential oils were tested for antimicrobial activity by using disc diffusion and micro dilution methods for the minimum inhibitory concentration (MIC). The results showed that the leaves oil exhibited significant antimicrobial activity towards Staphylococcus aureus with MIC value $250 \mu \mathrm{g} /$ $\mathrm{mL}$, while stems oil showed the activity against Gram positive bacteria, Pseudomonas aeruginosa and fungal, Aspergillus niger each with MIC value $500 \mu \mathrm{g} / \mathrm{mL}$.

Keywords: Essential oil, Piperaceae, Piper arborescens, antimicrobial activity
Wan Mohd Nuzul Hakimi Wan Salleh

Department of Chemistry, Faculty of Science, Universiti Teknologi Malaysia (UTM), 81310 Skudai, Johor, Malaysia

Farediah Ahmad

Department of Chemistry, Faculty of Science, Universiti Teknologi Malaysia (UTM), 81310 Skudai, Johor, Malaysia

Khong Heng Yen

School of Chemistry and Environment Studies, Faculty of Applied Sciences, Universiti Teknologi MARA (UiTM) Sarawak, Jalan Meranek, 94300 Kota Samarahan, Sarawak, Malaysia

\section{Corresponding author:}

Farediah Ahmad

E-mail:farediah@kimia.fs.utm.my

Tel: +6075534137

Fax: +6075566162

Submitted/Gönderilme: 28.01.2015 Accepted/Kabul: 04.03.2016
Revised/Düzeltme: 02.03 .2016

\section{INTRODUCTION}

The genus Piper has a large number of species and has been of worldwide interest due to their wide utilization as aromatic species and their use in the traditional medicine. Analysis of volatile constituents from Piperaceae species has revealed the presence of monoterpenes, sesquiterpenes and arylpropanoids that have shown interesting biological properties including cytotoxic, fungistatic, insecticide, molluscicidal, antioxidant and antimicrobial activities (15). As part of an exhaustive research of the composition of the essential oils of the aromatic and medicinal plants from Malaysia, we report herein the results of the investigation from Piper arborescens Roxb. P. arborescens is a climber and rarely shrub, distributed in Peninsular Malaysia, Philippines and Taiwan. It is also used in traditional medicine for treating rheumatism (6). Phytochemical studies on this plant have led to the isolation of pyridone alkaloids, cyclobutanoid alkaloids and lignans (7-9). The methanolic stem extract of $P$. arborescens showed significant antiplatelet aggregation activity and cytotoxicity activities (9), while chloroform stems extract was found to display significant activity against a KB cell culture system and a P-388 lymphocytic leukemia system in cell culture (10). 
A literature survey revealed no report on the antimicrobial activity of the essential oil of this plant, so this paper reports the essential oil components of the leaves and stems of $P$. arborescens together with their antimicrobial activity for the first time.

\section{MATERIAL AND METHODS}

\section{Plant materials}

Samples of $P$. arborescens were collected from Sarawak, Malaysia, in July 2010. This species was identified by Mrs. Mohizar Mohamad from the Forest Research Centre, Kuching, Sarawak and the voucher specimen (UiTMKS3001) was deposited at Natural Products Research \& Development Centre (NPRDC), UiTM Sarawak.

\section{Extraction of essential oils}

The fresh leaves and stems were subjected to hydrodistillation in an all glass Dean-stark apparatus for 5 hours. The oils were dried over anhydrous magnesium sulfate and stored at $4-6^{\circ} \mathrm{C}$. The oil yields $(\mathrm{w} / \mathrm{w})$ were $0.24 \%$ and $0.16 \%$ for leaves and stems, respectively based on the fresh weight.

\section{Gas chromatography (GC)}

GC analyses were performed on a Hewlett Packard 6890 series II A gas chromatograph equipped with an Ultra-1 column (100\% polymethylsiloxanes) (25 m long, $0.33 \mu \mathrm{m}$ thickness and $0.20 \mathrm{~mm}$ inner diameter). Helium was used as a carrier gas at flow rate of $0.7 \mathrm{~mL} / \mathrm{min}$. Injector and detector temperature were set at $250^{\circ} \mathrm{C}$ and $280^{\circ} \mathrm{C}$, respectively. Oven temperature was kept at $50^{\circ} \mathrm{C}$, then gradually raised to $280^{\circ} \mathrm{C}$ at $5^{\circ} \mathrm{C} / \mathrm{min}$ and finally kept isothermally for $15 \mathrm{~min}$. Diluted samples $(1 / 100$ in diethyl ether, $\mathrm{v} / \mathrm{v})$ of $1.0 \mu \mathrm{L}$ were injected manually (split ratio 50:1). The injection was repeated three times and the peak area percentages were reported as means $\pm S D$ of triplicates. Calculation of peak area percentage was carried out by using the GC HP Chemstation Software (Agilent Technologies).

\section{Gas chromatography-mass spectrometry (GC-MS)}

GC-MS chromatograms were recorded using a Hewlett Packard Model 5890A gas chromatograph and a Hewlett Packard Model 5989A mass spectrometer. The GC was equipped with Ultra-1 column ( $25 \mathrm{~m}$ long, $0.33 \mu \mathrm{m}$ thickness and $0.20 \mathrm{~mm}$ inner diameter). Helium was used as a carrier gas at a flow rate of $1 \mathrm{~mL} / \mathrm{min}$. Injector temperature was $250^{\circ} \mathrm{C}$. Oven temperature was programmed from $50^{\circ} \mathrm{C}(5$ min hold) at $10^{\circ} \mathrm{C} / \mathrm{min}$ to $250^{\circ} \mathrm{C}$ and finally kept isothermally for $15 \mathrm{~min}$. For GC-MS detection, an electron ionization system, with ionization energy of $70 \mathrm{eV}$ was used. A scan rate of $0.5 \mathrm{~s}$ (cycle time: $0.2 \mathrm{~s}$ ) was applied, covering a mass range from 50-400 amu.

\section{Identification of components}

The chemical components of the essential oils were identified by comparing their MS to the reference spectra in the computer library (Wiley) and also by comparing their retention indices and Kovats index in the literature data (11). The quantitative data were obtained electronically from FID area percentage without the use of correction factor.

\section{Antimicrobial activity}

The tested microorganism, Staphylococcus aureus (ATCC29737), Bacillus subtilis (ATCC6633), Pseudomonas aeruginosa (ATCC9027), Pseudomonas putida (ATCC49128), Escherichiacoli(ATCC10536), Candidaalbicans(ATCC10231) and Aspergillus niger (ATCC16888) were purchased from Mutiara Scientific, Cheras, Kuala Lumpur, Malaysia. The bacteria were cultured overnight at $35^{\circ} \mathrm{C}$ in Nutrient broth (NB) and fungi were cultured overnight at $30^{\circ} \mathrm{C}$ in Potato dextrose broth (PDB) which were further adjusted to obtain a turbidity comparable to that of Mc Farland standard tube No. 0.5 for further use.

Antimicrobial activity of the essential oils of $P$. arborescens was determined by agar disc diffusion method (12). The essential oils were dissolved in DMSO $(4 \mathrm{mg} / \mathrm{mL})$. Antimicrobial test were carried out by using $400 \mu \mathrm{L}$ of suspension containing $10^{8} \mathrm{CFU} / \mathrm{mL}$ of bacteria and $10^{6} \mathrm{CFU} / \mathrm{mL}$ of fungi, spread on the Nutrient agar (NA) and Potato dextrose agar (PDA) media, respectively. The disc (6 mm diameter) impregnated with $10 \mu \mathrm{L}$ of the essential oils and DMSO (negative control) was placed on the inoculated agar, and was incubated for 24 $\mathrm{h}$ at $35^{\circ} \mathrm{C}$ (bacteria) and $48 \mathrm{~h}$ at $30^{\circ} \mathrm{C}$ (fungi). Streptomycin sulfate $(10 \mu \mathrm{g} / \mathrm{mL})$ and nystatin (100 IU) were used as positive controls for bacteria and fungi, respectively. Clear inhibition zones around the discs indicated the presence of antimicrobial activity. All tests and analysis were carried out in triplicates.

Minimum inhibitory concentration (MIC) was determined by broth micro dilution method using 96-well microplates (12). Each test sample (1 mg) was dissolved in DMSO (1 mL) to get $1000 \mu \mathrm{g} / \mathrm{mL}$ stock solution. A number of wells were reserved in each plate for positive and negative controls. Sterile broth $(100 \mu \mathrm{L})$ was added to well from row B to $\mathrm{H}$. The stock solutions of samples $(100 \mu \mathrm{L})$ were added to wells at row A and B. Then, the mixture of samples and sterile broth (100 $\mu \mathrm{L}$ ) at row B were transferred to each well in order to obtain a twofold serial dilution of the stock samples (concentration of $1000,500,250,125,62.5,31.3,15.6$ and $7.8 \mu \mathrm{g} / \mathrm{mL})$. The inoculated bacteria $(100 \mu \mathrm{L})$ were added to each well. After an incubation period at $37^{\circ} \mathrm{C}$ for $16-20 \mathrm{~h}$, turbidity was taken as indication of growth, thus the lowest concentration which 
remained clear was taken as the MIC value. The MIC was recorded as the mean concentration of triplicates.

\section{Statistical analysis}

Data obtained from essential oil analysis and antimicrobial activities was expressed as mean values. The statistical analyses were carried out by employing one way ANOVA $(\mathrm{p}>0.05)$. A statistical package (SPSS version 11.0) was used for the data analysis.

\section{RESULTS AND DISCUSSION}

The chemical composition of the leaves and stems oil of $P$. arborescens is listed in Table 1. A total of fifty components were identified from both oils. Thirty six components, contributing $97.5 \%$ of the leaves oil had been identified. Monoterpene hydrocarbon (71.0\%) was the most dominant group in the leaves oil with $\beta$-phellandrene (24.3\%), sabinene (16.3\%) and $\alpha$-pinene (10.4\%) being the major components. Other significant components which gave more than $3 \%$ were terpinen-4-ol (7.2\%), limonene (5.4\%), $\gamma$-terpinene (3.6\%), $\alpha$-terpinene (3.4\%), $\beta$-caryophyllene (3.4\%) and bicyclogermacrene (3.3\%). The stems oil yielded forty six components constituting $90.5 \%$ of the total oil. In contrast to the leaves oil, the stems oil was rich in sesquiterpene hydrocarbon (38.8\%). They comprised of $\beta$-phellandrene (20.4\%), $\beta$-caryophyllene (9.0\%), bicyclogermacrene (4.5\%), $\alpha$-amorphene (3.1\%), $\beta$-selinene (3.0\%), $\alpha$-gurjunene (2.9\%), sabinene $(2.9 \%)$ and $\alpha$-humulene (2.9\%). Monoterpene hydrocarbon only contributed $31.9 \%$ compared to $71.0 \%$ of the components in the leaves oil. Most of the compounds found in the stems oil are also present in the leaves oil. The major differences found is the percentage of methyl eugenol which was found at $11.0 \%$ in the stems but $0.3 \%$ in the stems oil. $\alpha$-Pinene existed in $10.4 \%$ in the leaves but $2.1 \%$ in the stems oil. Sabinene dominated $16.3 \%$ in the leaves and detected only $2.9 \%$ in the stems while terpinen-4-ol constituted $7.2 \%$ in the leaves oil and present in $1.4 \%$ in the stems oil. In addition, $\alpha$-thujene, $\alpha$-terpinene, $(E)$ - $\beta$-ocimene and $\alpha$-guaiene were absent in the stems oil.

$\beta$-Phellandrene the major component for both oils, is known to be used in fragrances due to the pleasing aroma (13). Previous study on the essential oil from leaves of $P$. arborescens detected a-eudesmol, a-caryophyllene, globulol, and ( $Z$ )nerolidol as the major components (14). In comparison, all these components were not detected in this study was probably due to the different environmental and genetic factors, chemotypes and nutritional status of the plants, which may influence the essential oil composition (15).
Table 1. Constituents identified in the essential oils of $P$. arborescens

\begin{tabular}{|c|c|c|c|c|}
\hline \multirow[t]{2}{*}{ Components } & \multirow[t]{2}{*}{$\mathbf{K I}^{\mathbf{a}}$} & \multirow[t]{2}{*}{$\mathbf{K I}^{\mathbf{b}}$} & \multicolumn{2}{|c|}{ Percentage (\%) } \\
\hline & & & Leaf & Stem \\
\hline a-Thujene & 924 & 925 & $3.4 \pm 0.1$ & - \\
\hline$\alpha$-Pinene & 932 & 932 & $10.4 \pm 0.1$ & $2.1 \pm 0.1$ \\
\hline Camphene & 946 & 946 & $0.5 \pm 0.2$ & $0.4 \pm 0.1$ \\
\hline Sabinene & 970 & 969 & $16.3 \pm 0.2$ & $2.9 \pm 0.1$ \\
\hline Myrcene & 988 & 985 & $2.11 \pm 0.1$ & $0.9 \pm 0.1$ \\
\hline$\beta$-Phellandrene & 1002 & 1005 & $24.3 \pm 0.1$ & $20.4 \pm 0.1$ \\
\hline$\delta$-3-Carene & 1008 & 1008 & - & $0.2 \pm 0.2$ \\
\hline$\alpha$-Terpinene & 1014 & 1014 & $3.4 \pm 0.1$ & - \\
\hline Limonene & 1024 & 1024 & $5.4 \pm 0.2$ & $2.5 \pm 0.1$ \\
\hline (Z)- $\beta$-Ocimene & 1032 & 1030 & $0.3 \pm 0.2$ & $0.4 \pm 0.2$ \\
\hline (E)- $\beta$-Ocimene & 1044 & 1045 & $0.4 \pm 0.2$ & - \\
\hline$\gamma$-Terpinene & 1055 & 1054 & $3.6 \pm 0.3$ & $1.6 \pm 0.1$ \\
\hline a-Terpinolene & 1086 & 1086 & $0.9 \pm 0.3$ & $0.5 \pm 0.2$ \\
\hline Linalool & 1092 & 1092 & $1.5 \pm 0.1$ & $1.5 \pm 0.3$ \\
\hline Camphor & 1142 & 1142 & $0.1 \pm 0.3$ & $0.2 \pm 0.2$ \\
\hline Terpinen-4-ol & 1175 & 1175 & $7.2 \pm 0.3$ & $1.4 \pm 0.3$ \\
\hline$\alpha$-Terpineol & 1186 & 1186 & $0.4 \pm 0.1$ & $0.1 \pm 0.1$ \\
\hline a-Cubebene & 1346 & 1345 & $0.6 \pm 0.3$ & $0.7 \pm 0.1$ \\
\hline a-Copaene & 1374 & 1374 & $0.3 \pm 0.2$ & $2.3 \pm 0.1$ \\
\hline$\beta$-Bourbonene & 1387 & 1386 & - & $0.1 \pm 0.1$ \\
\hline$\beta$-Cubebene & 1388 & 1386 & - & $0.2 \pm 0.2$ \\
\hline$\beta$-Elemene & 1390 & 1389 & - & $1.8 \pm 0.1$ \\
\hline Methyl eugenol & 1404 & 1405 & $0.3 \pm 0.3$ & $11.0 \pm 0.1$ \\
\hline a-Gurjunene & 1406 & 1405 & $1.0 \pm 0.2$ & $2.9 \pm 0.2$ \\
\hline a-Cedrene & 1410 & 1410 & $0.4 \pm 0.3$ & $0.1 \pm 0.3$ \\
\hline$\beta$-Caryophyllene & 1418 & 1417 & $3.4 \pm 0.3$ & $9.0 \pm 0.2$ \\
\hline a-Guaiene & 1437 & 1435 & $0.3 \pm 0.2$ & - \\
\hline Aromadendrene & 1440 & 1440 & $0.2 \pm 0.1$ & $0.4 \pm 0.3$ \\
\hline a-Humulene & 1452 & 1452 & - & $2.9 \pm 0.1$ \\
\hline Dehydroaromadendrene & 1460 & 1460 & - & $0.6 \pm 0.1$ \\
\hline a-Amorphene & 1483 & 1482 & $1.2 \pm 0.1$ & $3.1 \pm 0.3$ \\
\hline Germacrene D & 1485 & 1485 & $0.1 \pm 0.2$ & $0.3 \pm 0.2$ \\
\hline$\beta$-Selinene & 1488 & 1487 & $1.1 \pm 0.2$ & $3.0 \pm 0.1$ \\
\hline Cadina-1,4-diene & 1495 & 1495 & - & $0.3 \pm 0.3$ \\
\hline a-Selinene & 1498 & 1498 & - & $1.9 \pm 0.3$ \\
\hline a-Muurolene & 1502 & 1502 & $0.3 \pm 0.1$ & $0.2 \pm 0.1$ \\
\hline Bicyclogermacrene & 1503 & 1502 & $3.3 \pm 0.2$ & $4.5 \pm 0.2$ \\
\hline$(E, E)$ - $\alpha$-Farnesene & 1505 & 1505 & $0.6 \pm 0.2$ & $0.4 \pm 0.1$ \\
\hline$\delta$-Cadinene & 1520 & 1520 & $0.6 \pm 0.1$ & $1.5 \pm 0.1$ \\
\hline$\beta$-Sesquiphellandrene & 1522 & 1520 & $2.2 \pm 0.2$ & $2.1 \pm 0.1$ \\
\hline cis-Calamenene & 1528 & 1528 & - & $0.1 \pm 0.1$ \\
\hline Germacren & 1560 & 1560 & $0.4 \pm 0.3$ & $0.4 \pm 0.1$ \\
\hline Spathulenol & 1578 & 1578 & $0.1 \pm 0.1$ & $0.1 \pm 0.1$ \\
\hline Caryophyllene oxide & 1582 & 1585 & $0.1 \pm 0.2$ & $0.4 \pm 0.2$ \\
\hline Globulol & 1592 & 1590 & - & $1.1 \pm 0.1$ \\
\hline Viridiflorol & 1595 & 1595 & - & $0.9 \pm 0.1$ \\
\hline Ledol & 1602 & 1600 & $0.8 \pm 0.2$ & $0.6 \pm 0.2$ \\
\hline t-Muurolol & 1645 & 1645 & - & $0.7 \pm 0.3$ \\
\hline a-Cadinol & 1650 & 1652 & - & $1.4 \pm 0.2$ \\
\hline$\alpha$-Bisabolol & 1685 & 1685 & - & $0.4 \pm 0.1$ \\
\hline Group compc & & & & \\
\hline Phenylpropa & & & $0 . .3$ & 11.0 \\
\hline Monoterpene hydrocarbons & & & 71.0 & 31.9 \\
\hline Oxygenated monoterpenes & & & 9.2 & 3.2 \\
\hline Sesquiterpene hydrocarbons & & & 16.0 & 38.8 \\
\hline Oxygenated sesc & & & 1.0 & 5.6 \\
\hline Identified components (\%) & & & 97.5 & 90.5 \\
\hline
\end{tabular}

${ }^{\mathrm{a}}$ Kovat indices (KI) experimental; ${ }^{\mathrm{b}} \mathrm{KI}$ literature (11) 
Antimicrobial activity of $P$. arborescens was determined by using disc diffusion and MIC methods against bacteria, yeast and fungi as shown in Table 2. The inhibition zones of disc and MIC values were in the range 7.0-12.2 $\mathrm{mm}$ and 250-1000 $\mu \mathrm{g} / \mathrm{mL}$, which signified that both oils possessed moderate antibacterial activity against the tested microorganisms. The leaves oil showed the activity against Gram-positive bacteria, B. subtilis and S. aureus with MIC values $250 \mu \mathrm{g} / \mathrm{mL}$ each, while the stems oil was only active towards $P$. putida with MIC values $500 \mu \mathrm{g} / \mathrm{mL}$. The essential oils also exhibited moderate activity against $A$. niger with MIC value $500 \mu \mathrm{g} /$ $\mathrm{mL}$. The leaves and stems oils of $P$. arborescens appeared to be more active against the bacteria. Gram-positive bacteria seemed to be more sensitive to the observe essential oils than Gram-negative bacteria due to the differences in the cell membrane of these bacterial groups (16). The antimicrobial properties of the essential oils are assumed to be associated with their oxygenated compounds (17). However, small amounts of the oxygenated components in both oils resulted in moderate antimicrobial activity.

Piper arborescens Roxb.'in Uçucu Yağ Bileșenlerinin Antimikrobiyel Etkileri

\section{ÖZ}

Piper arboresanın'un yaprak ve saplarından hidrodistilasyonla elde edilen uçucu yağlar GC ve GC-MS ile analiz edildi. Yaprak ve sap uçucu yağlarında sırasıyla otuzaltı bileşik (\% 97.5) ve kırkaltı bileşik (\% 90.5) olmak üzere elli bileşik tanımlanmıştır. Yaprak uçucu yağı içinde en bol bulunan bileşenler $\beta$-fellandren (\% 24.3), sabinen (\% 16.3), a-pinen (\% 10.4) ve terpinen-4-ol (7.2\%) iken sap uçucu yağında ise $\beta$-fellandren (\% 20.4), metil
Table 2. Antimicrobial activity of the essential oils of $P$. arborescens

\begin{tabular}{|c|c|c|c|c|c|}
\hline \multicolumn{2}{|l|}{ Test microbes } & \multirow{2}{*}{$\begin{array}{c}\text { Leaf oil } \\
8.2 \pm \\
0.2\end{array}$} & \multirow{2}{*}{$\begin{array}{c}\text { Stem oil } \\
7.4 \pm 0.3\end{array}$} & \multirow{2}{*}{$\begin{array}{c}\text { SS } \\
17.2 \pm 0.4\end{array}$} & \multirow{2}{*}{$\begin{array}{c}\text { NYS } \\
-\end{array}$} \\
\hline $\begin{array}{l}\text { Bacillus } \\
\text { subtilis }\end{array}$ & $\mathrm{DD}^{\mathrm{a}}$ & & & & \\
\hline & $\mathrm{MIC}^{\mathrm{b}}$ & 500 & 1000 & 7.8 & - \\
\hline $\begin{array}{l}\text { Staphylococcus } \\
\text { aureus }\end{array}$ & $\mathrm{DD}$ & $\begin{array}{c}11.0 \pm \\
0.3\end{array}$ & $7.5 \pm$ & $17.8 \pm 0.5$ & - \\
\hline & MIC & 250 & 1000 & 7.8 & - \\
\hline Pseudomonas & $\mathrm{DD}$ & NI & NI & $17.2 \pm 0.2$ & - \\
\hline aerugino & MIC & $>1000$ & $>1000$ & 7.8 & - \\
\hline $\begin{array}{l}\text { Pseudomonas } \\
\text { putida }\end{array}$ & $\mathrm{DD}$ & $\begin{array}{c}7.2 \pm \\
0.2\end{array}$ & $12.2 \pm 0.4$ & $17.3 \pm 0.5$ & - \\
\hline & MIC & $>1000$ & 500 & 7.8 & - \\
\hline Escherichia & DD & NI & NI & $17.5 \pm 0.4$ & - \\
\hline coli & MIC & $>1000$ & $>1000$ & 7.8 & - \\
\hline $\begin{array}{l}\text { Candida } \\
\text { albicans }\end{array}$ & $\mathrm{DD}$ & $\begin{array}{c}7.2 \pm \\
0.3\end{array}$ & $7.0 \pm 0.2$ & - & $15.2 \pm 0$. \\
\hline & MIC & $>1000$ & $>1000$ & - & 7.8 \\
\hline $\begin{array}{l}\text { Aspergillus } \\
\text { niger }\end{array}$ & DD & $\begin{array}{c}7.8 \pm \\
0.2\end{array}$ & $8.2 \pm 0.4$ & - & $15.3 \pm 0.2$ \\
\hline & MIC & 500 & 500 & - & 7.8 \\
\hline
\end{tabular}

Data represent mean \pm standard deviation of three independent experiments;

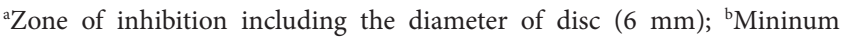
inhibitory concentration $(\mu \mathrm{g} / \mathrm{mL})$; SS - streptomycin sulphate; NYS nystatin; NI - no inhibition

öjenol (\% 11.0) ve $\beta$-karyofillen (\% 9.0) bulunmuştur. Uçucu yağlar, minimum inhibe edici konsantrasyon (MIC) belirlemek için disk difüzyon ve mikro seyreltme yöntemleri kullanılarak, antimikrobiyal aktivite bakımından test edilmiştir. Yaprak yağı Staphylococcus aureus'a karşı $250 \mathrm{ug} / \mathrm{mL}$ MIC değeri ile kayda değer aktivite gösterirken, sap yağı ise Pseudomonas aeruginosa Gram pozitif bakterilere ve Aspergillus niger mantara karşı, her biri için $500 \mathrm{ug} / \mathrm{mL}$ MIC değerinde aktivite göstermiştir.

Anahtar kelimeler: Uçucu yağ, Karabibergiller, Piper arborescens, antimikrobiyal aktivite

\section{CONCLUSION}

The result demonstrated that $\beta$-phellandrene, sabinene, $\alpha$-pinene, terpinen-4-ol, methyl eugenol and $\beta$-caryophyllene were the most abundant components in $P$. arborescens oils. In the case of $P$. arborescens oils, although there is no striking on their antimicrobial activity in the leaf and stem oils, it is still worthwhile to investigate the other parts of the plant as a natural source for essential oil composition or phytochemical studies. In conclusion, the essential oils and their components generally displayed significant bioactivity properties, which are useful in daily life in foods and as preventive agents from various diseases. However, further investigation should be carried out on their activities against other foodborne pathogens.

\section{ACKNOWLEDGMENTS}

The authors thank the Research University Grant (GUP) for financial support under vote QJ130000.2526.03H93 (GUP) and the Department of Chemistry, Faculty of Science, Universiti Teknologi Malaysia (UTM) for research facilities.

\section{REFERENCES}

1. Parmar VS, Jain SC, Bisht KS, Jain R, Taneja P, Jha A, Tyagi OD, Prasad AK, Wengel J, Olsen CE, Boll PM. Phytochemistry of the genus Piper. Phytochemistry 1997; 46: 597-673.

2. Martins AP, Salguero L, Vila R, Tomi F, Canigueral S, Casanova J, Proenca da Cunha A, Adzet T. Essential oils from Piper species. Phytochemistry 1998; 49: 2019-23.

3. Santos PRD, Moreira DL, Guimaraes EF, Kaplan MAC. 
Essential oil analysis of 10 Piperaceae species from the Brazilian Atlantic forest. Phytochemistry 2001; 58: 547-51.

4. Costantin MB, Sartorelli P, Limberger R, Henriques AT, Steppe M, Ferreira MJP, Ohara MT, Emerenciano VP, Kato MJ. Essential oils from Piper cernuum and Piper regnellii: Antimicrobial activities and analysis by GC/MS and 13C-NMR. Planta Med 2001; 67: 771-3.

5. Navickiene HMD, Morandim AA, Alecio AC, Regasini LO, Bergamo DCB, Telascrea M, Cavalheiro AJ, Lopes MN, Bolzani VS, Furlan M, Marques MOM, Young MCM, Kato MJ. Composition and antifungal activity of essential oils from Piper aduncum, Piper arboreum and Piper tuberculatum. Quim Nova 2006; 29: 467-70.

6. Lin TT, Lu SY. Piperaceae in Flora of Taiwan, $2^{\text {nd }}$ Edition, Editorial Committee of the Flora of Taiwan, Taipei, Taiwan, 1996.

7. Duh CY, Wu YC, Wang SK. Cytotoxic pyridone alkaloids from Piper aborescens. Phytochemistry 1990; 29: 2689-91.

8. Lee FP, Chen YC, Chen JJ, Tsai IL, Chen IS. Cyclobutanoid Amides from Piper arborescens. Helvet Chim Acta 2004; 87: 463-8.

9. Tsai IL, Lee FP, Wu CC, Duh CY, Ishikawa T, Chen JJ, Chen YC, Seki H, Chen IS. New cytotoxic cyclobutanoid amides, a new furanoid lignin and anti-platelet aggregation constituents from Piper aborescens. Planta Med 2005; 71: 535-42.

10. Geran RI, Greenberg NH, Macdonald MM, Schumacher AM, Abbott BJ. Protocols for screening chemical agents and natural products against animal tumors and other biological systems. Cancer Chemother Rep 1972; 7: 7-9.
11. Adams RP. Identification of essential oil by gas chromatographyquadrupole/mass spectroscopy, $4^{\text {th }}$ Ed. Allured Publishing Corporation, Carol Stream IL, USA, 2001.

12. Salleh WMNHW, Ahmad F, Yen KH. Chemical compositions and antimicrobial activity of the essential oils of Piper abbreviatum, $P$. erecticaule and P. lanatum (Piperaceae). Nat Prod Commun 2014; 9: 1795-8.

13. Jirovetz L, Buchbauer G, Abraham GT, Shafi MP. Chemical composition and olfactory characterization of Acmella radicans (Jacq.) R.K. Jansen var. radicans from southern India. Flavour Frag J 2006; 21: 88-91.

14. Chieng TC, Assim ZB, Fasihuddin BA. The essential oil composition of the leaves of five Piper species for taxonomic purposes. ACGC Chem Res Commun 2005; 19: 6-12.

15. Marjo K, Eija P, James ES. Variation in volatile compounds from tansy (Tanacetum vulgare L.) related to genetic and morphological differences of genotypes. Biochem Syst Ecol 2001; 29: 267-85.

16. Filippi JJ, Lanfranchi DA, Prado S, Baldovini N, Meierhenrich UJ. Composition enantiomeric distribution and antibacterial activity of the essential oil of Achillea ligustica All from Corsica. J Agric Food Chem 2006; 54: 6308-13.

17. Marzoug HNB, Romdhane M, Lebrihi A, Mathieu F, Couderc F, Abderraba M, Khouja ML, Bouajila J. Eucalyptus oleosa essential oils: Chemical composition and antimicrobial and antioxidant activities of the oils from different plant parts (Stems, Leaves, Flowers and Fruits). Molecules 2011; 16: 16951709. 